\title{
Inheritance of Resistance to Papaya Ringspot Virus-Watermelon Strain in Watermelon
}

\author{
Nihat Guner \\ Sakata Seed America, Inc., Morgan Hill, CA 95037 \\ Zvezdana Pesic-VanEsbroeck \\ Department of Entomology and Plant Pathology, North Carolina State \\ University, Raleigh, NC 27695
}

Luis A. Rivera-Burgos ${ }^{1}$ and Todd C. Wehner

Department of Horticultural Science, North Carolina State University, Raleigh, NC 27695

Additional index words. Citrullus lanatus, single recessive gene, allelism test, plant introduction

\begin{abstract}
Sources of resistance to the watermelon strain of papaya ringspot viruswatermelon strain (PRSV-W) have been identified within the watermelon (Citrullus lanatus) germplasm collection. Inheritance of the resistance to PRSV-W was studied in three Citrullus amarus (formerly C. lanatus var. citroides) PI accessions: PI 244017, PI 244019, and PI 485583. Three susceptible parent lines, 'Allsweet', 'Calhoun Gray', and 'New Hampshire Midget', were crossed with resistant $P I$ accessions to develop $F_{1}, F_{2}$, and $\mathrm{BC}_{1}$ progenies in six families. A single recessive gene was found to control the resistance to PRSV-W in all three resistant PI accessions. Allelism tests indicated that the three PI accessions carry the same resistance allele to PRSV-W. The gene symbol 'prv' is proposed for PRSV-W resistance in PI 244017, PI 244019, and PI 485583 in watermelon.
\end{abstract}

\section{Introduction}

Watermelon [C. lanatus (Thunb.) Matsum. \& Nakai] is a major cucurbit crop that accounts for $7.5 \%$ of the world area devoted to vegetable crops (FAO, 2015). Worldwide, watermelons are grown on more than 3.4 million ha, with a production of more than 111 million $\mathrm{Mg}$ of fruit. China and the Middle Eastern countries are the major producers and consumers (FAO, 2015). In the United States, watermelon is used fresh as a dessert and in salads. Major production states in the United States are Florida, California, Texas, Georgia, and North Carolina (USDA, 2017). Production increased from 1.2 million $\mathrm{Mg}$ in 1987 to 5.1 million $\mathrm{Mg}$ in 2017, with a farm value of \$579 million (USDA, 2017).

Plant diseases caused by viruses are a major limiting factor in the commercial production of watermelon worldwide. Around the world, more than 10 viruses are known to be a problem in watermelon production (Ali et al., 2012; Wang et al., 2017). The major viruses affecting watermelon in the United States are PRSV-W [formerly Watermelon mosaic virus-1 (WMV-1)], WMV [formerly Watermelon mosaic virus-2 (WMV-2)], and Zucchini yellow mosaic virus. All three viruses are nonpersistently transmitted by several species of aphids, and mixed infections

Received for publication 31 Jan. 2018. Accepted for publication 1 Mar. 2018.

${ }^{1}$ Corresponding author. E-mail: larive2@ncsu.edu. are common (Ali et al., 2012; Chen et al., 2008; Morata and Puigdomènech, 2017; Wehner et al., 2001). Virus diseases are destructive to the watermelon crop and are difficult to control (Kone et al., 2017; NavasCastillo et al., 2011). Chemical control of the vectors is not usually efficient to control the disease. Cultural controls such as treatment with mineral oil sprays, light-reflective surfaces, and cross-protection with weak PRSV-W isolates show limited effectiveness and require additional input costs. Therefore, genetic resistance remains the simplest, most effective, and most efficient mean of limiting losses to these diseases (Ali et al., 2012; Levi et al., 2016; Nagendran et al., 2017; Yu et al., 2011).

PRSV-W affects all agricultural species of the Cucurbitaceae and is of great economic importance because of its destructiveness (Ali et al., 2012; Morata and Puigdomènech, 2017). PRSV-W was first described by Webb and Scott (1965) from Asia in Sri Lanka (Bateson et al., 2002). For many years, PRSV-W was considered to be the distinct potyvirus, WMV-1 (Webb and Scott, 1965). However, the $\mathrm{P}$ and $\mathrm{W}$ isolates were found to be indistinguishable serologically (Gonsalves and Ishii, 1980) and now are considered to be strains of PRSV (Baker et al., 1991; Purcifull and Hiebert, 1979; Purcifull et al., 1984). The main reason for the early confusion about the taxonomic status of the $\mathrm{W}$ isolate was that it does not infect papaya. However, the $\mathrm{P}$ isolates infect cucurbits in nature as well as papaya (Provvidenti, 1993).
PRSV-W is transmitted in a nonpersistent manner by 24 aphid species in 15 genera with Myzus persicae, Aulacorthum solani, Aphis craccivora, and Macrosiphum euphorbiae as natural vectors. PRSV-W is a potyvirus whose genome consists of unipartite, singlestranded, linear RNA. Its total genome size is $12 \mathrm{~kb}$, and the genome codes for eight proteins. PRSV-W is in the family Potyviridae. PRSV-W induces pinwheel and scroll types of cytoplasmic cylindrical inclusions in infected host cells (Tiwari and Rao, 2014). Type $\mathrm{W}$ isolates are reported to infect 38 species in 11 genera of Cucurbitaceae, and two species of Chenopodiaceae, with squash (Cucurbita spp.), watermelon (C. lanatus), cucumber (Cucumis sativus), and melon (Cucumis melo) among the commercially important natural hosts (Freitas and Rezende, 2008). The virus is not seed transmitted. It appears to overwinter in wild species of Cucurbitaceae and Chenopodiaceae (Purcifull and Hiebert, 1979).

Symptoms of severe PRSV-W infection in cucurbits include leaves with mosaic, puckering, blistering, and size reduction; vines that are stunted; and fruit that are small, knobby, malformed, and mottled (Tiwari and Rao, 2014). PRSV-W causes significant yield reduction in watermelon, squash, melon, cucumber, and other cultivated cucurbits (Turechek et al., 2010).

Researchers have screened cucurbit species other than watermelon for resistance to PRSV-W, and the inheritance of the resistance has been determined. Sources of resistance to PRSV-W have been found in cucumber (C. sativus), melon (C. melo), and squash (Cucurbita spp.). PRSV-W resistance is controlled by a single recessive gene in cucumber (Tian et al., 2015) and a single dominant gene in melon (Pitrat and Lecoq, 1983). In squash, resistance to PRSV-W is controlled by a single recessive gene in C. moschata (Bolanos-Herrera, 1994) and by three partially dominant genes in C. maxima (Maluf et al., 1997).

Sources of resistance to PRSV-W have been reported in watermelon. Strange et al. (2002) screened the USDA watermelon germplasm collection and reported PRSV-W resistance in three PI accessions from South Africa (PI 244017, PI 244018, and PI 244019), three PI accessions from Zimbabwe (PI 482342, PI 482318, and PI 482379), one PI accession from Botswana (PI 485583), and one PI accession from Nigeria (PI 595203). All of the resistant PI accessions except PI 595203 are C. amarus (formerly C. lanatus var. citroides). PI 595203 is Citrullus mucosospermus (Chomicki and Renner, 2015).

Although there has been no report of inheritance for resistance to PRSV-W in watermelon accessions (PI 244017, PI 244019, and PI 485583), Azevedo et al. (2012) reported that PRSV-W resistance in watermelon accession PI 595201 was not a simple monogenic inheritance pattern, although additive effects were found. PI 595203 was reported to have a low level of resistance in the extensive PRSV-W watermelon screening by Strange et al. (2002). 
The objective of this study was to determine the inheritance of PRSV-W resistance in three resistant PI accessions (PI 244017, PI 244019, and PI 485583) and to test the resistance genes in the three PI accessions for allelism. Based on previous studies in other cucurbits, we hypothesize that the inheritance of the resistance to PRSV-W follows the single gene mode of inheritance.

\section{Materials and Methods}

Plant material. The parental lines used in this study were watermelon cultivars Allsweet (ALS), New Hampshire Midget (NHM), and Calhoun Gray (CHG) that are highly susceptible to PRSV-W; and PI 244017, PI 244019, and PI 485583 that are highly resistant. PI accessions were obtained from the Southern Regional Plant Introduction Station at Griffin, GA. ALS, CHG, and NHM were used as susceptible parents because they have high fruit yield and quality (Wehner, 2002). All crosses were made using controlled, hand-pollination in the greenhouse of the Department of Horticultural Science at North Carolina State University in Raleigh, NC. Six families were developed from six crosses, ALS $\times$ PI 244019, ALS $\times$ PI 485583, $\mathrm{CHG} \times \mathrm{PI} 244019, \mathrm{NHM} \times \mathrm{PI}$ 244017, $\mathrm{NHM} \times \mathrm{PI} 244019$, and $\mathrm{NHM} \times$ PI 485583. The $F_{1}$ was self-pollinated and backcrossed to their respective parental lines, to obtain progenies $\mathrm{F}_{2}, \mathrm{BC}_{1} \mathrm{P}_{\mathrm{s}}$, and $\mathrm{BC}_{1} \mathrm{P}_{\mathrm{r}}$ for all six crosses. Each family contained six progenies: $\mathrm{P}_{\mathrm{s}}, \mathrm{P}_{\mathrm{r}}, \mathrm{F}_{1}, \mathrm{~F}_{2}, \mathrm{BC}_{1} \mathrm{P}_{\mathrm{s}}$, and $\mathrm{BC}_{1} \mathrm{P}_{\mathrm{r}}$. For each of the six crosses, 180 plants were tested: $5 \mathrm{P}_{\mathrm{s}}, 5 \mathrm{P}_{\mathrm{r}}, 10 \mathrm{~F}_{1}, 100 \mathrm{~F}_{2}, 30 \mathrm{BC}_{1} \mathrm{P}_{\mathrm{s}}$, and $30 \mathrm{BC}_{1} \mathrm{P}_{\mathrm{r}}$ plants were used to test the inheritance from each cross.

Planting and management. The inheritance study was performed in the greenhouse of the Department of Plant Pathology at North Carolina State University in Raleigh, NC. Greenhouse temperatures ranged from 23 to $43{ }^{\circ} \mathrm{C}(0800-2000 \mathrm{~h})$ and 12 to $24{ }^{\circ} \mathrm{C}$ (20000-0800 h). We seeded directly in plastic pots $\left(100 \times 100 \mathrm{~m}^{2}\right.$ size, $600-\mathrm{mL}$ volume $)$ filled with a soilless mix (Canadian sphagnum moss, perlite, vermiculite, processed pine bark). We planted two seeds per pot and thinned to one to ensure a uniform experiment (Gusmini et al., 2017).

Inoculum preparation. The virus isolate for this study was obtained from D.E. Purcifull, University of Florida, Gainesville, FL. PRSV-W isolate 2052 was a severe isolate described by Baker et al. (1991) and was maintained on 'Gray Zucchini' squash (Cucurbita pepo L.) from Seminis Vegetable Seeds (Woodland, CA). The inoculum was prepared by grinding infected 'Gray Zucchini' leaves using a mortar and pestle in $0.02 \mathrm{M}$ phosphate buffer, $\mathrm{pH}$ 7.0. Leaf to buffer ratio was 1:5 (1 g infected leaf to $5 \mathrm{~mL}$ buffer).

To maintain the PRSV-W isolate and increase inoculum, we used the rub method (Guner et al., 2002). Squash plants were inoculated by dusting one leaf on each 3-week-old plant with 800-mesh carborundum, then applying the inoculum to the leaf with a pestle which was rotated in a circular motion 8-10 times as if painting the leaf with inoculum. After inoculation, carborundum was rinsed off the leaves to improve light interception, and the plants were maintained in aphid-proof cages. All 'Gray Zucchini' plants were seeded in Metro-Mix 200 (Scotts-Sierra Horticultural Products Company, Marysville, $\mathrm{OH}$ ) in $160 \mathrm{~mm}$ diameter (1550 mL volume) clay pots. Plants were fertilized weekly with $150 \mathrm{mg} \cdot \mathrm{kg}^{-1}$ Peters Professional 20-20-20 N-P-K (ScottsSierra Horticultural Products Company).

Inoculation and data collection. The previously described inoculation procedure to maintain the PRSV-W isolate and increase inoculum in squash plants was also used for the inheritance study in watermelon (Guner et al., 2002). Plants were inoculated at the first true leaf stage and weekly rated at least six times 2 weeks after the inoculation. We used a scale of 1 to 9 on the basis of severity of viral symptoms, where $0=$ none, $1-2=$ trace, $3-4=$ slight, $5-6=$ moderate, $7-8=$ severe, and $9=$ plant dead (Guner et al., 2002). After the last rating, plants were tested by using ELISA (Agdia Incorporated, Elkhart, IN) to determine the presence of the virus in the leaf tissue. Leaf tissue used for testing was sampled from the top five leaves of the plant. Plants were classified as resistant or susceptible based on their rank relative to the estimated mean value of the disease severity scale (6.0) and ELISA test results. Plants which did not have the virus in their system and had an average rating $<6.0$ were considered resistant, and plants with the virus in their system and an average rating $>6.0$ were considered susceptible (Strange et al., 2002).

Statistical analysis. The $\chi^{2}$ tests for goodness-of-fit $(P<0.05)$ and homogeneity were used to examine segregation ratios (susceptible:resistant) for each $\mathrm{F}_{2}$ and $\mathrm{BC}_{1}$ $\mathrm{P}_{\mathrm{r}}$ progeny with the SAS statistical package (SAS Institute, Inc., Cary, NC) and the SASGene 1.2 program (Liu et al., 1997).

Yates' correction was used for those chisquare tests where counts were $\leq 5$ for any class in the ratio. However, there was no difference in the conclusion, so we presented the data without the correction to avoid the tendency of Yate's to overcorrect (Haviland, 1990).

Allelism test. To determine the allelic association between the resistance genes in the three PI accessions (PI 244017, PI 244019, and PI 485583) we conducted the allelism test in the greenhouses. The resistant PI accessions were crossed to each other in all possible combinations using controlled pollinations to generate $F_{1}$ progenies. All $\mathrm{F}_{1}$ hybrids derived from resistant $\times$ resistant crosses were inoculated with PRSV-W and phenotypically scored for non-complementation using the same inoculation procedure and rating system used in the inheritance study (Guner et al., 2002). Each $F_{1}$ progeny was self-pollinated to generate $F_{2}$ seeds. To confirm the allelism test conducted in $\mathrm{F}_{1}$ plants, $\mathrm{F}_{2}$ progenies were planted, inoculated, and rated as before.

\section{Results}

All crosses between susceptible parents and resistant parents produced uniformly susceptible $F_{1}$ progenies, indicating that PRSV-W resistance is a recessive trait. The $\mathrm{F}_{2}, \mathrm{BC}_{1} \mathrm{P}_{\mathrm{s}}$, and $\mathrm{BC}_{1} \mathrm{P}_{\mathrm{r}}$ progenies from all six crosses were tested to the expected ratios of a single gene inheritance. The $\mathrm{F}_{2}$ segregation data obtained from all crosses followed the expected ratio of 3 susceptible :1 resistant, favoring the single gene inheritance hypothesis (Table 1). All $\mathrm{BC}_{1} \mathrm{P}_{\mathrm{s}}$ progenies also supported the expected ratio for a single recessive gene hypothesis, showing 1 susceptible : 0 resistant ratio (Table 1). All $\mathrm{BC}_{1} \mathrm{P}_{\mathrm{r}}$ populations segregated 1 susceptible : 1 resistant ratio, which also confirms a single recessive gene mode of inheritance controlling the resistance to PRSV-W in PI 244017, PI 244019, and PI 485583 (Table 1). The pooled $\mathrm{F}_{2}$ individuals segregated 436 susceptible : 154 resistant with a $\chi^{2}$ of $0.35(\mathrm{df}=1)$, showing that the data were consistent with a 3:1 ratio (Table 2). The $P$ value for that $\chi^{2}$ also confirmed a good fit of the data to the predicted values $(P$ value $=0.55)$. The homogeneity $\chi^{2}$ (with $\mathrm{df}=5$ ) for the $\mathrm{F}_{2}$ was 0.99 , indicating that all crosses represented the same progeny and were homogenous (Table 2).

To determine whether the resistance genes of the PI accessions were allelic, we performed the allelism test. The PI accessions were crosses in all possible combination to generate $\mathrm{F}_{1}$ progenies $(\mathrm{PI} 244017 \times \mathrm{PI}$ 244019, PI $244017 \times$ PI 244019, and PI $485583 \times$ PI 244019 ). The progenies were evaluated using the same inoculation procedure used in the inheritance study. Also, $\mathrm{F}_{2}$ progenies were generated and tested to confirm allelic reactions observed in the $F_{1}$ progenies. We observed that all $F_{1}$ and $F_{2}$ progenies were resistant to PRSV-W, indicating that the resistance genes in all three resistant PI accessions are allelic (data not shown).

\section{Discussion}

The PRSV has a serious impact on watermelon production in the United States. Most of the time, PRSV-W outbreaks result in losses through a reduction in growth, yield, and fruit quality. There are two pathotypes of this potyvirus: PRSV-P (papaya strain) that infects papaya (Carica papaya) and most of the cucurbitaceous crops (Cucurbitaceae), and PRSV-W (watermelon strain) that exclusively infects cucurbitaceous crops (Cucurbitaceae) (Freitas and Rezende, 2008; Romay et al., 2014). The virus can be transmitted in a nonpersistent, noncirculative manner by several aphid species (Aphididae), and also by mechanical inoculation, but not via seeds (Tiwari and Rao, 2014). Some of 
Table 1. Single locus goodness-of-fit test $(P<0.05)$ for resistance to Papaya ringspot virus-watermelon strain in watermelon.

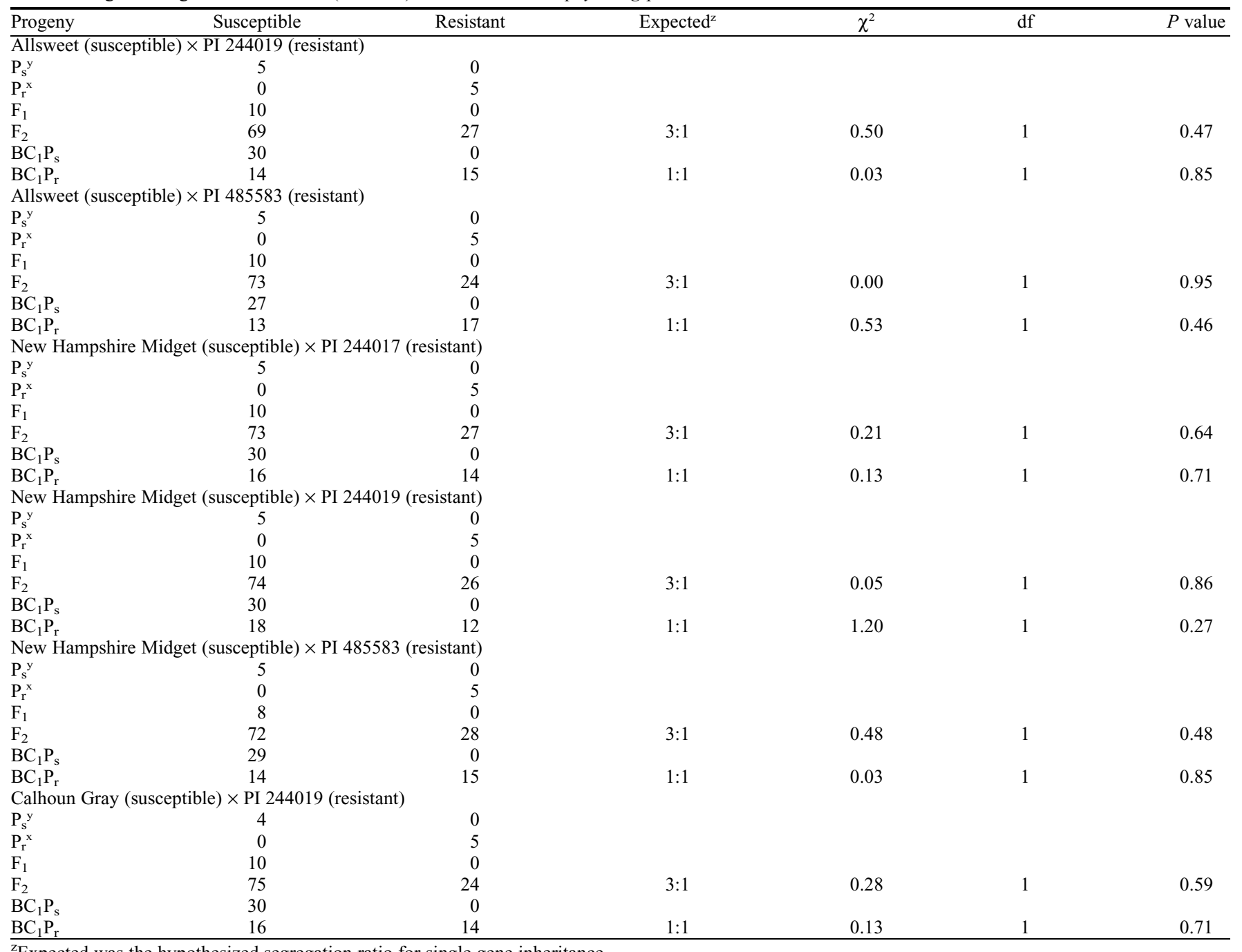

${ }^{\mathrm{z}}$ Expected was the hypothesized segregation ratio for single gene inheritance.

${ }^{\mathrm{y}} \mathrm{P}_{\mathrm{s}}$ was the susceptible parent.

${ }^{\mathrm{x}} \mathrm{P}_{\mathrm{r}}$ was the resistant parent.

Table 2. Pooled and homogeneity data from the six crosses for resistance to Papaya ringspot virus-watermelon strain in watermelon.

\begin{tabular}{|c|c|c|c|c|c|c|}
\hline Progeny & Susceptible & Resistant & Expected $^{\mathrm{z}}$ & $\chi^{2}$ & $\mathrm{df}$ & $P$ value \\
\hline$P_{s}{ }^{y}$ & 29 & 0 & & & & \\
\hline $\mathrm{P}_{\mathrm{r}}^{\mathrm{x}}$ & 0 & 30 & & & & \\
\hline $\mathrm{F}_{1}$ & 58 & 0 & & & & \\
\hline $\mathrm{BC}_{1} \mathrm{P}_{\mathrm{s}}$ & 176 & 0 & & & & \\
\hline $\mathrm{BC}_{1} \mathrm{P}_{\mathrm{r}}$ & 91 & 87 & $1: 1$ & 0.08 & 1 & 0.76 \\
\hline Homogeneity & & & & 1.18 & 5 & 0.99 \\
\hline
\end{tabular}

${ }^{\mathrm{z}}$ Expected was the hypothesized segregation ratio for single gene inheritance.

${ }^{{ }^{y}} P_{s}$ was the susceptible parent.

${ }^{\mathrm{x}} \mathrm{P}_{\mathrm{r}}$ was the resistant parent.

the symptoms consist of mosaic, the presence of blisters and deformations on leaves, fruit malformation with a change in color, and plant stunting. In the field, PRSV-W outbreaks are quite difficult to control, leaving breeding for disease resistance as the most suitable method to control PRSV-W epidemics. Hence, the use of commercial cultivars with high resistance to PRSV-W would stabilize yield and improve fruit quality in watermelon production areas worldwide (Ali et al., 2012; Nagendran et al., 2017; Romay et al., 2014; Turechek et al., 2010).

It is common for plant breeders to identify cultigens that serve as a source of resistance, although the genetic basis of the resistance has not been previously determined. As already reported, the PI watermelon accessions 244017,244019 , and 485583 showed high resistance to PRSV-W epidemics (Strange et al., 2002). However, it was not determined whether these PI accessions carry one or more genes controlling the resistance to PRSV-W. In this study, these three PI accessions were tested for the inheritance of PRSV-W on segregating progenies from crosses with susceptible lines. The inheritance data indicated that the resistance to PRSV-W, in all three resistant PI accessions, was controlled by a single recessive gene. Similar results were also reported on the inheritance of the resistance to PRSV-W on watermelon PI accession 595203 (Ma et al., 2005). In other cucurbitaceous crops, such as cucumber (C. sativus L.) and melon (C. melo L.), 
it was also reported that the resistance to PRSV-W was controlled by a single gene (Anagnostou et al., 2000; Tian et al., 2015; Wai and Grumet, 1995). Our results from the inheritance study and allelism test confirm the hypothesis that PRSV-W resistance in PI 244017, PI 244019, and PI 485583 is controlled by the same single recessive gene. We propose naming this new gene Papaya ringspot virus resistance, with the symbol 'prv', in conformance with gene nomenclature rules for the Cucurbitaceae (Wehner, 2012).

\section{Literature Cited}

Ali, A., O. Mohammad, and A. Khattab. 2012. Distribution of viruses infecting cucurbit crops and isolation of potential new virus-like sequences from weeds in Oklahoma. Plant Dis. 96:243-248.

Anagnostou, K., M. Jahn, and R. Perl-Treves. 2000. Inheritance and linkage analysis of resistance to Zucchini yellow mosaic virus, $\mathrm{Wa}$ termelon mosaic virus, Papaya ringspot virus and powdery mildew in melon. Euphytica 116:265-270.

Baker, C.A., H. Lecoq, and D.E. Purcifull. 1991. Serological and biological variability among Papaya ringspot virus type- $\mathrm{W}$ isolates in Florida. Phytopathology 81:722-728.

Bateson, M., R.E. Lines, P. Revill, W. Chaleeprom, C.V. Ha, A.J. Gibbs, and J.L. Dale. 2002. On the evolution and molecular epidemiology of the potyvirus Papaya ringspot virus. J. Gen. Virol. 83:2575-2585.

Bolanos-Herrera, A.B. 1994. Inheritance of virus resistance in Cucurbita moschata and C. maxima. Cornell Univ., Ithaca, NY.

Chen, K-C., C-H. Chiang, J.A.J. Raja, F-L. Liu, C-H. Tai, and S-D. Yeh. 2008. A single amino acid of niapro of Papaya ringspot virus determines host specificity for infection of papaya. Mol. Plant Microbe Interact. 21:1046-1057.

Chomicki, G. and S.S. Renner. 2015. Watermelon origin solved with molecular phylogenetics including Linnaean material: Another example of museomics. New Phytol. 205:526-532.

de Azevedo, S.M., W.R. Maluf, M.V. Faria, J.T.V. de Resende, C.B. de Menezes, and I.R. do Nascimento. 2012. Inheritance of resistance to the Papaya ringspot virus-watermelon strain (PRSV-W) from watermelon accession "PI 595201". Crop Breed. Appl. Biotechnol. 12:67-75.

FAO. 2015. FAO statistical pocketbook. FAO Stat. Div., Rome, Italy.

Freitas, D.M.S. and J.A.M. Rezende. 2008. Protection between strains of Papaya ringspot virus: Type $\mathrm{W}$ in zucchini squash involves competition for viral replication sites. Sci. Agr. 65:183-189.
Gonsalves, D. and M. Ishii. 1980. Purification and serology of Papaya ringspot virus. Phytopathology 70:1028-1032.

Guner, N., E.B. Strange, T.C. Wehner, and Z. Pesic-VanEsbroeck. 2002. Methods for screening watermelon for resistance to $\mathrm{Pa}$ paya ringspot virus type-W. Scientia Hort. 94:297-307.

Gusmini, G., L.A. Rivera-Burgos, and T.C. Wehner. 2017. Inheritance of resistance to gummy stem blight in watermelon. HortScience 52:1477-1482.

Haviland, M.G. 1990. Yate's correction for continuity and the analysis of $2 \times 2$ contingency tables. Stat. Med. 9:363-367.

Kone, N., E. Asare-Bediako, S. Silue, D. Kone, O. Koita, W. Menzel, and S. Winter. 2017. Influence of planting date on incidence and severity of viral disease on cucurbits under field condition. Ann. Agr. Sci. 62:99-104.

Levi, A., J. Coffey, L. Massey, N. Guner, E. Oren, Y. Tadmor, and K.S. Ling. 2016. Resistance to Papaya ringspot virus-watermelon strain (PRSV-W) in the desert watermelon Citrullus colocynthis. HortScience 51:4-7.

Liu, J.S., T.C. Wehner, and S.B. Donaghy. 1997. SASGENE: A SAS computer program for genetic analysis of gene segregation and linkage. J. Hered. 88:253-254.

Ma, S., Y. Xy, G. Gong, H. Zhang, and H. Shen 2005. Analysis on the inheritance of resistance to PRSV-W and ZYMV-CH and their linkage in watermelon. J. Fruit Sci. 22:731733.

Maluf, W.R., J.J. Pereira, and A.R. Figueira. 1997. Inheritance of resistance to the Papaya ringspot virus-watermelon strain from two differen accessions of winter squash Cucurbita maxima Duch. Euphytica 94:163-168.

Morata, J. and P. Puigdomènech. 2017. Variability among Cucurbitaceae species (melon, cucumber and watermelon) in a genomic region containing a cluster of NBS-LRR genes. BMC Genomics 18:1-7.

Nagendran, K., S. Mohankumar, R. Aravintharaj, C.G. Balaji, S.K. Manoranjitham, A.K. Singh, A.B. Rai, B. Singh, and G. Karthikeyan. 2017. The occurrence and distribution of major viruses infecting cucurbits in Tamil Nadu state, India. Crop Protection 99:10-16.

Navas-Castillo, J., E. Fiallo-Olivé, and S. SánchezCampos. 2011. Emerging virus diseases transmitted by whiteflies. Annu. Rev. Phytopathol. 49:219-248.

Pitrat, M. and H. Lecoq. 1983. Two alleles for Watermelon mosaic virus 1 resistance in melon. Rep. Cucurbit Genet. Coop. 6:52-53.

Provvidenti, R. 1993. Resistance to viral diseases of cucurbits, p. 8-43. In: M.M. Kyle (ed.). Resistance to viral diseases of vegetables: Genetics and breeding. Timber Press, Inc., Portland, OR.
Purcifull, D.E., J.R. Edwardson, E. Hoebert, and D. Gonsalves. 1984. Papaya ringspot virus. CMI/ AAB Descr. Plant Viruses 292:8.

Purcifull, D.E. and E. Hiebert. 1979. Serological distinction of Watermelon mosaic virus isolates. Phytopathology 69:112-116.

Romay, G., H. Lecoq, and C. Desbiez. 2014. Cucurbit crops and their viral diseases in Latin America and the Caribbean islands: A review. J. Plant Pathol. 96:227-242.

Strange, E., N. Guner, Z. Pesic-VanEsbroeckb, and T. Wehner. 2002. Screening the watermelon germplasm collection for resistance to Papaya ringspot virus type-W. Crop Sci. 42:13241330.

Tian, G., Y. Yang, S. Zhang, H. Miao, H. Lu, Y. Wang, B. Xie, and X. Gu. 2015. Genetic analysis and gene mapping of Papaya ring spot virus resistance in cucumber. Mol. Breeding $35: 110$

Tiwari, A.K. and G.P. Rao. 2014. Viruses infecting Cucurbita pepo: Current status and management, p. 357-371. In: R.N. Kharwar, R.S. Upadhyay, N.K. Dubey, R. Raghuwanshi (eds.). Microbial diversity and biotechnology in food security. Springer, New Delhi, India.

Turechek, W.W., C.S. Kousik, and S. Adkins. 2010. Distribution of four viruses in single and mixed infections within infected watermelon plants in Florida. Phytopathology 100:1194-1203.

USDA. 2017. Agricultural statistics. Washington, D.C

Wai, T. and R. Grumet. 1995. Inheritance of resistance to the watermelon strain of Papaya ringspot virus the cucumber line TMG-1. HortScience 39:338-340.

Wang, D., G. Li, and S.S. Du. 2017. Occurrence of viruses infecting melon in Xinjiang of China and molecular characterization of Watermelon mosaic virus isolates. Eur. J. Plant Pathol. 147:919-931.

Webb, R.E. and H.A. Scott. 1965. Isolation and identification of watermelon mosaic viruses 1 and 2. Phytopathology 55:895-900.

Wehner, T.C. 2002. Vegetable cultivar descriptions for North America list 26. HortScience 34:957-1012.

Wehner, T.C. 2012. Watermelon gene list. Rep Cucurbit Genet. Coop. 36:40-64.

Wehner, T.C., N.V. Shetty, and G.W. Elmstrom. 2001. Breeding and seed production, p. 27-73. In: D.N. Maynard (ed.). Watermelon: Characteristics, production, and marketing. ASHS Press, Alexandria, VA.

Yu, T.A., C.H. Chiang, H.W. Wu, C.M. Li, C.F. Yang, J.H. Chen, Y.W. Chen, and S.D. Yeh. 2011. Generation of transgenic watermelon resistant to Zucchini yellow mosaic virus and Papaya ringspot virus type W. Plant Cell Rep. 30:359-371. 